Hydrol. Earth Syst. Sci. Discuss., https://doi.org/10.5194/hess-2018-163

Manuscript under review for journal Hydrol. Earth Syst. Sci.

Discussion started: 31 May 2018

\title{
The effect of initial water distribution and spatial resolution on the interpretation of ERT monitoring of water infiltration in a landfill cover
}

\author{
Gaël Dumont $^{1,2}$, Tamara Pilawski ${ }^{1}$, Thomas Hermans ${ }^{1,3}$, Frédéric Nguyen ${ }^{1}$, Sarah Garré $^{2}$
}

$5 \quad{ }^{1}$ Urban and Environmental Engineering, University of Liege, Liège, 4000, Belgium

${ }^{2}$ TERRA Teaching and Research Center, University of Liege, Gembloux, Agro-Bio Tech, Gembloux, 5030, Belgium

${ }^{3}$ Departement of Geology, University of Ghent, Ghent, 9000, Belgium

Correspondence to: Gaël Dumont (gdumont@uliege.be)

Abstract. In a landfill, the biodegradation of the organic fraction of the waste is driven by its moisture. Once the waste dump

10 is covered, the infiltration through the cover layer is a source of additional water. In this study, the changes in water content in a landfill cover layer were investigated with long time-lapse electrical resistivity tomography (ERT) profiles. Measurements carried out during a rainfall event allowed the detection of zones with large infiltration events. We addressed all interpretation limits inherent to such a large scale, low resolution investigation with the use of synthetic modelling. Firstly, the smoothed resistivity changes distribution failed to detect small infiltration areas and induced a misestimation of the infiltration depth and

15 volume in large infiltration zones. Secondly, when the background water content is not homogeneous, relative changes, as commonly used in literature, reflect both the background moisture distribution and the monitored changes. Thirdly, the temperature and pore fluid conductivity distribution are needed to compute the absolute water content changes. The latter better reflects the infiltration pattern. Lastly, rain water infiltration results in pore water dilution. When the dilution effect is not considered, the infiltrated volume is underestimated. This approach enabled us to detect a large infiltration zone that could be responsible for an important part of the annual water infiltration.

\section{Introduction}

There is a wide interest to quantify the dynamics of water content in unsaturated media, for instance to investigate water infiltration (e.g. Beff et al., 2013), solute transfer (e.g. Koestel et al., 2008) or water storage (e.g. Beff et al., 2013; Jayawickreme et al., 2008). In municipal solid waste (MSW) landfills, the water content is of uttermost importance for the waste biodegradation process (e.g. Reinhart and Townsend, 1997): a low water content, due to low permeability of the cover layer, can hamper the biodegradation. In bioreactor landfills, many efforts are undertaken to increase the water content within the waste. This can be done when filling the cell by dripping, irrigating or spraying (e.g. Reinhart and Townsend, 1997). However, the water content continues to evolve once the temporary cover layer is in place, due to infiltration of rain water. The amount of infiltration depends on the climate, the slope and the cover layer. Defective or cracked cover layers are likely 
Hydrol. Earth Syst. Sci. Discuss., https://doi.org/10.5194/hess-2018-163

Manuscript under review for journal Hydrol. Earth Syst. Sci.

Discussion started: 31 May 2018

(c) Author(s) 2018. CC BY 4.0 License.

the main contributors to rain water infiltration (e.g. Albright et al., 2004). The water content can also be increased artificially through infiltration trenches and pounds or leachate recirculation under the cover layer (e.g. Reinhart and Townsend, 1997).

Among the numerous methods to measure the water content in the vadose zone, most consist in taking local measurements (i.e. Imhoff et al., 2007; Jayawickreme et al., 2008). However, point measurements fail to represent heterogeneously distributed

5 moisture content. Spatially distributed proxies for moisture content can be obtained using geophysical methods, such as surface or borehole electrical resistivity tomography (ERT) (Binley et al., 2015, 2002b; Daily et al., 1992; Dumont et al., 2016; Garré et al., 2013; Grellier et al., 2007; Guérin et al., 2004), given the decrease of bulk electrical resistivity with the increase of water content (Archie, 1942). In addition, ERT may provide high temporal resolution information to capture the main infiltration process at the scale of a few tens of minutes.

10 The value of geophysics in characterizing the water content of former landfills, for example to improve biogas production or material recycling through landfill mining, has been increasingly studied in the past decades. Many studies (Dumont et al., 2016; Grellier et al., 2007, 2006; Guérin et al., 2004; Imhoff et al., 2007) have shown the potential of ERT in characterizing the moisture content in municipal solid waste landfills, but also the difficulty to discriminates the effects of water content, pore fluid conductivity (Archie, 1942) and temperature (Campbell et al., 1948) on the bulk electrical resistivity. To avoid this non-

15 uniqueness of the interpretation, water recirculation experiments can be monitored with time lapse ERT (e.g. Audebert et al., 2014; Clément et al., 2011, 2010; Grellier et al., 2008, 2006; Guérin et al., 2004) for example to isolate one varying parameter. Time lapse ERT data are generally interpreted in terms of relative changes of electrical resistivity (Clément et al., 2010; Doetsch et al., 2012; Hermans et al., 2015; Miller et al., 2008; Pellet et al., 2016; Robert et al., 2012) or equivalently Eq. (1) as a function of the ratio of monitored electrical resistivity and initial electrical resistivity (e.g. Auken et al., 2014; Brunet et

20 al., 2010; Doetsch et al., 2015; Power et al., 2015):

$$
\frac{\rho_{2}-\rho_{1}}{\rho_{1}}=\frac{\rho_{2}}{\rho_{1}}-1 \text {, }
$$

where subscript 1 stand for the reference (also referred to as baseline or background) acquisition and 2 for the monitored time frame. However, when analyzing changes of water content in the vadose zone, the initial water content (the parameter of interest) distribution is generally not homogeneous. The relative changes therefore reflect both the temporal changes and the

25 heterogeneity in the initial distribution. For identical additional water content, zones with a high initial water content will display little to no changes in resistivity upon an infiltration event despite flow occurring, whereas dry zones might encounter large changes. Due to this duality, electrical resistivity results in vadose zone monitoring are often interpreted qualitatively and not quantified in terms of water content variation. For monitoring water content in landfills, researchers generally attempts to quantify specific parameters such as the evolution of the infiltration front depth with time or the water plume geometry and extension to provide a humidified volume. For example, Clément et al. (2011) defined a percentage change threshold representative of the physical extension of a leachate plume without using any petrophysical relationship. The plume geometry can be used to deduce the anisotropy of water flow (Audebert et al., 2016a) or to calibrate the retention capacity, the permeability at saturation and its anisotropy in hydrogeological unsaturated flow models (Audebert et al., 2016b). In other 
Hydrol. Earth Syst. Sci. Discuss., https://doi.org/10.5194/hess-2018-163

Manuscript under review for journal Hydrol. Earth Syst. Sci.

Discussion started: 31 May 2018

(c) Author(s) 2018. CC BY 4.0 License.

research fields, such as the study of the vadose zone water content, water storage dynamics or plant water uptake, the direct estimation of water content from bulk electrical resistivity data using empirical or calibrated pedophysical relationships is more common, probably because these media, although also complex, are less heterogeneous than landfill covers (e.g. Beff et al., 2013; Garré et al., 2013, 2012; Jayawickreme et al., 2008; Ma et al., 2014). study, we have two main objectives: (i) to

5 highlight and quantify the effect of limitations of field ERT data for waste management and (ii) to investigate water infiltration through a landfill cover layer during an intense rainfall event $(30 \mathrm{~mm}$ precipitation in 2 hours measured at nearest meteorological station, about $3 \mathrm{~km}$ away, but it may differ locally) using time-lapse ERT data. We here quantify the errors in water content estimation and the interpretation pitfalls from resistivity changes due to low ERT resolution, initial heterogeneous resistivity distribution, temperature and pore fluid conductivity, and to the dilution effect during fresh water

10 infiltration. We propose the use of synthetic modeling tools to investigate and avoid these pitfalls. The paper is organized as follows: In the material and methods section, we first describe the site and the experiments conducted in the laboratory and on the field. We discuss different factors influencing the bulk electrical resistivity and how numerical simulations can help us to investigation these factors. Then, we present the field results and associated interpretation challenges. We use virtual experiments (sand box experiment and vadose zone numerical modeling) to simulate the different conditions encountered on

15 the field. The observations made during the latter are used to deeper discuss the field results. We then conclude on the use of time-lapse ERT for the monitoring of water infiltration in a landfill cover layer.

\section{Material and methods}

\subsection{Site description}

The field survey was conducted on the Mont-Saint-Guibert site, one of the largest engineered landfills of Belgium (26 ha wide

20 and up to $60 \mathrm{~m}$ deep, Fig. 1). The landfill activity started in 1958 and the site was equipped with a synthetic liner at the bottom in the early $90 \mathrm{~s}$. The waste $\left(5.3\right.$ million $\left.\mathrm{m}^{3}\right)$ is mainly composed of municipal solid waste, non-hazardous and non-toxic industrial waste and bulky waste. Inert waste was used for the temporary cover layer.

ERT profile acquisitions were performed in July 2014 in the North side of the landfill, close to a peripheral drain surrounding

25 the deposit area (Figure 1b). In this zone of interest, waste was disposed at different periods of time. The $10 \mathrm{~m}$ superficial waste layer is about 10-12 years old. The topography is characterized by a $14 \%$ slope towards the S-W (Fig. 1). At that specific location, the waste deposit is about $30 \mathrm{~m}$ thick. The vadose zone is $15 \mathrm{~m}$ thick and below the waste is fully saturated with leachate. The waste material is covered by a temporary cover layer of minimum one meter thickness, composed of sandy and silty material coming from a nearby sand quarry. The cover layer thickness differs locally.

30 The hydraulic behavior of the cover layer is influenced by the density of the vegetation cover (typically dryer initial conditions where the vegetation is denser) and the cover layer composition (sand, silt, loam). Three main soil conditions (grain size and 
Hydrol. Earth Syst. Sci. Discuss., https://doi.org/10.5194/hess-2018-163

Manuscript under review for journal Hydrol. Earth Syst. Sci.

Discussion started: 31 May 2018

(c) Author(s) 2018. CC BY 4.0 License.

water content) coexist along this profile. The Eastern part of the monitoring zone is either bare or covered by grass. The soil is composed of silty and sandy material and stays relatively humid, even after dry meteorological conditions (one month without precipitation). The Western side of the test area is vegetated. The vegetation includes some small trees (birch, robinia, etc.) and bushes. In the vegetated area, the cover layer texture becomes coarser towards the middle of the profile. Due to a

5 lower retention capacity and a higher water uptake from plant's roots, the water content in this part of the site is quite low after a dry period. Based on ERT measurements, and considering a 1.25 to $2.5 \Omega$.m pore water resistivity, we converted the bulk electrical resistivity data measured on the field into volumetric water content values (0.23-0.33 in humid zones and 0.10-0.15 in dry zones

\subsection{Laboratory measurements of pore fluid and water content}

10 We estimated the pore fluid conductivity (or resistivity) heterogeneity for the cover layer and the waste material from 7 cover layer samples that were collected in September 2015 at $0.25 \mathrm{~m}$ depth. We measured the water content on samples of 300-600 $\mathrm{g}$ by drying the soil at $60^{\circ} \mathrm{C}$ during 1 week. Gravimetric water content ranged from 0.11 in the central zone to 0.24 at the eastern side. Then, the pore fluid conductivity was estimated by mixing a 20-60 g soil sample of known water content with $100 \mathrm{ml}$ of deionized water $(15 \mu \mathrm{S} / \mathrm{cm}$ conductivity, or $667 \Omega . \mathrm{m}$ resistivity). Supposing that electrical conductivity is

15 proportional to the TDS (Total Dissolved Solids) (e.g. Meju, 2006), the electrical conductivity of the mixed fluid is the average of deionized and pore fluid water, weighted by their respective volumes.

$\sigma_{\text {pore fluid }}=\frac{\sigma_{\text {mix }} *\left(M_{\text {sample }} * \theta_{\text {sample }}+V_{\text {deionized }}\right)-\sigma_{\text {deionized }} V_{\text {deionized }}}{M_{\text {sample }} * \theta_{\text {sample }}}$,

where $\sigma$ is the fluid electrical conductivity, $V$ is the volume, $M$ is the sample weight and $\theta$ is the soil sample water content. The laboratory experiment shows that the pore fluid resistivity at $0.25 \mathrm{~m}$ depth varies from $10 \Omega . \mathrm{m}$ in the center and coarse area,

20 2.5-3.3 $\Omega . \mathrm{m}$ in other zones of the profile and $0.9 \Omega . \mathrm{m}$ at the Eastern extremity. These measurements correlate the site setup: the vegetated Western zone is often flushed by fresh water runoff coming from uphill. This water mainly infiltrates in the coarse grain size area, leading to salt dilution and washing, which leads to a higher pore water resistivity in this area. The unusually low resistivity values observed in the Eastern extremity of the profile can most probably be explained by an ongoing uphill leachate recirculation experiment, which repeatedly triggered leachate overflow and cover layer contamination of this area with conductive fluid. The temperature of the cover layer has not been recorded but was likely close to $25^{\circ} \mathrm{C}$ during the ERT acquisition (late July). The temperature measured the day after in a horizontal drain at $2 \mathrm{~m}$ depth was about $30^{\circ} \mathrm{C}$.

The estimation of waste material water content and pore fluid resistivity at larger depth (up to $30 \mathrm{~m}$ ) results from borehole investigations performed in 2012 (location in Fig. 1, more details in Dumont et al., 2016). During the drilling operation, we gathered 301 waste samples every $2 \mathrm{~m}$ for bulk resistivity measurements in laboratory (Dumont et al., 2016). By applying a

3015 ton pressure on the waste samples, we recovered 100-200 ml leachate samples and measured their resistivity. In addition, distributed temperature sensing (DTS) measurements were performed in situ after installing the piezometer equipment to correct for temperature effects. In the $15 \mathrm{~m}$ thick unsaturated zone, the temperature increases from $25^{\circ} \mathrm{C}$ at the surface to $60^{\circ} \mathrm{C}$ 
Hydrol. Earth Syst. Sci. Discuss., https://doi.org/10.5194/hess-2018-163

Manuscript under review for journal Hydrol. Earth Syst. Sci.

Discussion started: 31 May 2018

(c) Author(s) 2018. CC BY 4.0 License.

at $15 \mathrm{~m}$ depth. The leachate resistivity (conductivity) varies from $1.25 \Omega . \mathrm{m}(8000 \mu \mathrm{S} / \mathrm{cm}$ ) at the surface (1m depth) to 0.28 $\Omega . \mathrm{m}(36000 \mu \mathrm{S} / \mathrm{cm})$ at $15 \mathrm{~m}$ depth. In the saturated zone, the temperature and the leachate resistivity are constant. We used these vertical profiles of temperature and pore fluid resistivity to establish synthetic models reproducing plausible electrical resistivity distributions. These distributions are not necessarily identical to the reality at our ERT profile location, but represent similar conditions, which allow us to simulate plausible numerical experiments. While the physical properties of the cover is of prior interest for the quantification of the infiltration process, the characteristics of the waste are less important since the infiltration front probably do not cross the cover layer during the monitored time interval.

\subsection{Electrical resistivity tomography acquisition and data processing}

For the ERT data acquisition, we used a $77.5 \mathrm{~m}$ long ERT line with 32 stainless steel electrodes and $2.5 \mathrm{~m}$ electrode spacing

10 (Fig. 1). The profile was perpendicular to the maximum slope (about 14\%). We used the multiple gradient protocol (Dahlin and Zhou, 2006) to acquire the resistivity data sets (288 quadrupoles / acquisition). The acquisition of an entire data set lasted for 13 minutes and was repeated every hour. In this study, we focus on data acquired 120 and 60 minutes before (background) and 60 minutes after the rainfall event.

We refer to Loke et al. (2013) for a detailed description of the electrical resistivity tomography (ERT) method. In short, a pair

15 of electrodes is used to inject an electrical current in the ground, and the created potential drop between two other electrodes is measured. The investigated depth and volume increase with the electrode spacing.

The data sets were inverted using the 2.5D inversion code CRTomo (Kemna, 2000). The horizontal cell size was half the electrode spacing and the vertical cell size was $0.5 \mathrm{~m}$. The inversion process was based on the minimization of an objective function composed of the data misfit constraint and the model constraint (e.g. Oldenburg and Li, 1994):

$20 \quad F=\left\|W_{d}(d-f(m))\right\|^{p}+\lambda\left\|W_{m} m\right\|^{p}$,

In Eq. (3), $W_{d}$ is the data weighing matrix, $d$ is the impedance data set $(\log ), m$ is the resistivity model $(\log ), f$ is the nonlinear operator mapping $d$ and $m, W_{m}$ is the roughness matrix and $\lambda$ is the regularization parameter. The error level on the data $W_{d}$ was estimated from reciprocal measurements (measurement taken while switching current electrodes with the potential electrodes). A conservative linear error model of the envelope of reciprocal errors, with an absolute error of $0.0005 \Omega$ and a relative error of $1 \%$, was considered during the inversion process (e.g. Slater et al., 2000). At each iteration, the regularization parameter $\lambda$ was optimized (de Groot-Hedlin and Constable, 1990; Kemna, 2000), then increased after the last iteration to fit exactly the imposed level of noise (error-weighted $\mathrm{CHI}^{2}=1$ ). In this study, the inversion process ended with a regularization parameter ranging from 10 to 30 (for low resolution data sets inversion) and 70 to 400 for high resolution data sets inversion). We used the difference inversion procedure (inversion of temporal changes in the data $d-d_{0}$ ) and the background model $m_{0}$

30 is used as a reference model for the regularization (LaBrecque and Yang, 2001).

$F=\left\|W_{d}\left(d-d_{0}+f\left(m_{0}\right)-f(m)\right)\right\|^{p}+\lambda\left\|W_{m}\left(m-m_{0}\right)\right\|^{p}$, 
Hydrol. Earth Syst. Sci. Discuss., https://doi.org/10.5194/hess-2018-163

Manuscript under review for journal Hydrol. Earth Syst. Sci.

Discussion started: 31 May 2018

(c) Author(s) 2018. CC BY 4.0 License.
Hydrology and

Earth System

Sciences

Discussions

\subsection{Factors influencing electrical resistivity}

Two site-specific petrophysical laws describing the influence of the water content, the pore fluid electrical resistivity (first law) and the temperature (second law) on the bulk electrical resistivity of the landfill waste were previously calibrated in the laboratory and validated on the field (Dumont et al., 2016). Archie's law (Archie, 1942; Wyllie and Gregory, 1953) expressed in terms of volumetric water content (Grellier et al., 2007) was used to describe the evolution of the bulk resistivity with the volumetric water content (porosity * saturation).

$$
\left.\rho_{b}=\rho_{w} a \emptyset^{-m} S^{-n} \cong \rho_{w} a \theta^{-m} \text { (if } m \cong n\right)
$$

where $\rho_{b}$ is the bulk electrical resistivity; $\rho_{w}$ is the electrical resistivity of the pore fluid; $a$ is the cementation constant; $m$ et $n$ are empiric constants related to the matrix structure, $\varnothing$ is the total porosity, $S$ is the saturation and $\theta$ is the volumetric water content of the sample. The influence of the volumetric water content on the bulk electrical resistivity was checked at the laboratory by preparing 18 samples ( 3 gravimetric water content $* 6$ different dry densities) and measuring their bulk resistivity in a test cell. From our laboratory experiments, we obtained $m=2.101$ and a $=1.53$ for the Archie's law parameters.

We performed heating and cooling cycles $\left(10-65^{\circ} \mathrm{C}\right)$ in a laboratory oven to quantify the influence of temperature on the electrical conductivity. We highlighted that a linear law (Campbell et al., 1948) fits the experimental data. The conductivity increases by $1.9 \%$ per degree of temperature (reference temperature at $20^{\circ} \mathrm{C} ; \mathrm{R}^{2}=1$ ).

$\sigma=\sigma_{T_{\text {ref }}} \cdot\left(1+c \cdot\left(T-T_{\text {ref }}\right)\right)$

Where $\sigma$ is the electrical conductivity at temperature T, $\sigma_{\mathrm{T}_{\mathrm{ref}}}$ is the electrical conductivity at the reference temperature $T_{\text {ref }}$ and $c$ is an empirical constant. The relations are used to convert bulk electrical resistivity data into water content, and inversely. Based on Archie's and Campbell's laws (Eq. (5-6)), the combined influence of these factors is represented by the following equation:

$$
\Delta \theta=\theta_{2}-\theta_{1}=\left(\frac{\left(1+c\left(T-T_{r e f}\right)\right)}{a \rho_{w, T_{-} r e f}}\right)^{-1 / m}\left(\rho_{2}^{-1 / m}-\rho_{1}^{-1 / m}\right)
$$

for which the parameter definitions are identical to the ones of Eq. (5-6). For small changes, the effect of uncertainty of pore fluid resistivity and temperature on the computation of the water content and water content changes are obtained upon derivation of Eq. (7) (also found in Brunet et al., 2010). For temperature, this results in the following expression:

$$
\frac{\Delta \theta}{\theta}=-\frac{1}{m} * \frac{c T}{1+c(T-20)} * \frac{\Delta T}{T}
$$

For the pore fluid resistivity, the impact is similarly expressed as:

$$
\frac{\Delta \theta}{\theta}=\frac{1}{m} \frac{\Delta \rho_{w}}{\rho_{w}}
$$

\subsection{Simulation of simplified vadose zone water dynamics in a virtual landfill cover layer}

A synthetic case was used to highlight the limitations that need to be taken into account for the interpretation of the monitored

resistivity changes. This simplified synthetic case shares common features with the field set-up but is not calibrated to it. The 
Hydrol. Earth Syst. Sci. Discuss., https://doi.org/10.5194/hess-2018-163

Manuscript under review for journal Hydrol. Earth Syst. Sci.

Discussion started: 31 May 2018

(c) Author(s) 2018. CC BY 4.0 License.

water content distribution for the synthetic case was computed with the finite element modelling code HYDRUS-2D (Šimůnek et al., 2012). The model is $77.5 \mathrm{~m}$ wide, the cover layer is $1 \mathrm{~m}$ thick and its grain size, based on local field observations, is fine (75\% $<0.25 \mathrm{~mm}$, for cover layer samples mentioned at section 2.1.) for the two extremities of the profile and coarser (50\% $>0.25 \mathrm{~mm}$, for cover layer samples mentioned at section 2.1.) in central part (Fig. 2a). A small grid size was used to represent

5 the infiltration process ( $0.125 \mathrm{~m}$ vertical resolution) and we used the van Genuchten-Mualem model (van Genuchten, 1980) to parametrize the hydraulic properties of our medium. The parameters of the unsaturated permeability model for the cover layer were in the range of values proposed by the Hydrus-2D data base for similar material (Table 1). The fine silty material was characterized by a $7.2 \mathrm{~mm} / \mathrm{h}(2 * 10-6 \mathrm{~m} / \mathrm{s})$ permeability at saturation. The coarser sandy material by a $36 \mathrm{~mm} / \mathrm{h}(10-5 \mathrm{~m} / \mathrm{s})$ permeability at saturation. We set the residual water content for both cover layer materials to 0.065 . The residual water content

10 of the waste material was higher than for inert sediment composing the landfill cover. It was set to 0.15 , as proposed by Audebert et al. (2016a) from a study of Stoltz et al. (2012) for similar conditions. For the waste, we set the permeability at saturation at $10-4 \mathrm{~m} / \mathrm{s}$ but it had no impact on the water flow anyhow, since no water infiltrated into this zone during the simulation.

We first simulated the infiltration of $200 \mathrm{~mm}$ water per year during four years, until the water content distribution reached an

15 equilibrium state. The computation time step was a fraction a second at first $(0.8 \mathrm{sec})$, then increased progressively to about 1 month (38 days), for the last computation step, in order to reduce the computation time. This spin-up procedure generated realistic initial conditions and avoided any strong water drainage and redistribution between the different horizons of the profile during the subsequent simulation of the rainfall event under investigation. Instead of modelling the impact of vegetation, we artificially reduced the water content of the vegetated part of the cover layer to 0.15 (after a period of prolonged drought in

20 July 2014) since we did not have the necessary data to model the water uptake by plants. This approach coarsely mimicked the effects caused by vegetation on the electrical resistivity changes but did not aim at simulating plants dynamics in relation to soil moisture. This simplified simulation approach resulted in an initial humidity condition close to the conditions observed on the site during the field ERT data acquisition which are discussed in this study: about 0.25 of water in the waste material, 0.33 in the bare cover layer, and 0.15 water content in the vegetated area (Table 2; Fig. 2b).

25 After the spin-up period, we simulated an intense precipitation event. The amount of water is larger than the cumulated precipitation recorded (between $20-30 \mathrm{~mm}$ at neighboring meteorological stations) on the real field site to account for water runoff from the uphill large bare area. In the simulation, the infiltrated quantity was imposed and was limited by the maximum infiltration capacity of the soil that is imposed by its permeability at saturation. The computation time step was 15 min and the water mass balance error remained below $0.2 \%$.

30 In our 2D model, we represented three distinct infiltration scenarios are found for the cover layer in the 2D model zones (Fig. 2abc). The first zone (Western zone) represents a dry cover layer (water content of 0.15) above wet waste material (water content of 0.25$)$. The infiltrated quantity of water $\left(14.41 / \mathrm{m}^{2}\right.$ in 2 hours' time) is limited by the permeability of the cover layer $(2.10-6 \mathrm{~m} / \mathrm{s})$. The second zone (central zone) is characterized by the same initial water content, but a larger permeability (10- 
Hydrol. Earth Syst. Sci. Discuss., https://doi.org/10.5194/hess-2018-163

Manuscript under review for journal Hydrol. Earth Syst. Sci.

Discussion started: 31 May 2018

(c) Author(s) 2018. CC BY 4.0 License.

$5 \mathrm{~m} / \mathrm{s}$ ). The infiltrated quantity of water is $721 / \mathrm{m}^{2}$ in 2 hours' time. The last zone (Eastern zone) is a humid cover layer (0.3 water content) above wet waste material, with the same permeability characteristics as in the first zone.

We converted the water content before and after the infiltration event into electrical resistivity (Fig. 2d), using the temperature and pore fluid resistivity distribution and the calibrated Archie's and Campbell's petrophysical laws (Eq. (5-6)). We used the

5 forward modelling code CRTomo (Kemna, 2000) to generate two virtual ERT data sets with the same vertical cell size as used for the simulation of the water dynamics with Hydrus. Noise was added to both data, based on field measured reciprocal errors. The standard deviation is half the measured noise on reciprocal field data, so that $95 \%$ of the simulated data errors are contained with the envelope error model used for data inversion (section 2.2.). Finally, the resistivity distribution and change obtained after the inversion process was converted into water content and compared to the infiltrated water distribution initially

10 computed with Hydrus2D.

In order to investigate the effect of electrode spacing on the resolution of the structures and phenomena under consideration, we generated ERT data for two electrode arrays: $0.5 \mathrm{~m}$ (grid size $0.125 \mathrm{~m}$ for inversion) and $2.5 \mathrm{~m}$ (grid size $0.5 \mathrm{~m}$ for inversion). The latter corresponds to the spacing we applied in our field experiment.

15 A synthetic case was used to highlight the limitations that need to be taken into account for the interpretation of the monitored resistivity changes. This simplified synthetic case shares common features with the field set-up but is not calibrated to it. The water content distribution for the synthetic case was computed with the finite element modelling code HYDRUS-2D (Šimůnek et al., 2012). The model is $77.5 \mathrm{~m}$ wide, the cover layer is $1 \mathrm{~m}$ thick and its grain size, based on local field observations, is fine ( $75 \%<0.25 \mathrm{~mm}$, for cover layer samples mentioned at section 2.1.) for the two extremities of the profile and coarser (50\%

$20>0.25 \mathrm{~mm}$, for cover layer samples mentioned at section 2.1.) in central part (Fig. 2a). A small grid size was used to represent the infiltration process ( $0.125 \mathrm{~m}$ vertical resolution) and we used the van Genuchten-Mualem model (van Genuchten, 1980) to parametrize the hydraulic properties of our medium. The parameters of the unsaturated permeability model for the cover layer were in the range of values proposed by the Hydrus-2D data base for similar material (Table 1). The fine silty material was characterized by a $7.2 \mathrm{~mm} / \mathrm{h}\left(2 * 10^{-6} \mathrm{~m} / \mathrm{s}\right)$ permeability at saturation. The coarser sandy material by a $36 \mathrm{~mm} / \mathrm{h}\left(10^{-5} \mathrm{~m} / \mathrm{s}\right)$

25 permeability at saturation. We set the residual water content for both cover layer materials to 0.065 . The residual water content of the waste material was higher than for inert sediment composing the landfill cover. It was set to 0.15 , as proposed by Audebert et al. (2016a) from a study of Stoltz et al. (2012) for similar conditions. For the waste, we set the permeability at saturation at $10^{-4} \mathrm{~m} / \mathrm{s}$ but it had no impact on the water flow anyhow, since no water infiltrated into this zone during the simulation.

30 We first simulated the infiltration of $200 \mathrm{~mm}$ water per year during four years, until the water content distribution reached an equilibrium state. The computation time step was a fraction a second at first $(0.8 \mathrm{sec})$, then increased progressively to about 1 month (38 days), for the last computation step, in order to reduce the computation time. This spin-up procedure generated realistic initial conditions and avoided any strong water drainage and redistribution between the different horizons of the profile during the subsequent simulation of the rainfall event under investigation. Instead of modelling the impact of vegetation, we 
Hydrol. Earth Syst. Sci. Discuss., https://doi.org/10.5194/hess-2018-163

Manuscript under review for journal Hydrol. Earth Syst. Sci.

Discussion started: 31 May 2018

(c) Author(s) 2018. CC BY 4.0 License.

artificially reduced the water content of the vegetated part of the cover layer to 0.15 (after a period of prolonged drought in July 2014) since we did not have the necessary data to model the water uptake by plants. This approach coarsely mimicked the effects caused by vegetation on the electrical resistivity changes but did not aim at simulating plants dynamics in relation to soil moisture. This simplified simulation approach resulted in an initial humidity condition close to the conditions observed

5 on the site during the field ERT data acquisition which are discussed in this study: about 0.25 of water in the waste material, 0.33 in the bare cover layer, and 0.15 water content in the vegetated area (Table 2; Fig. 2b).

After the spin-up period, we simulated an intense precipitation event. The amount of water is larger than the cumulated precipitation recorded (between 20-30 mm at neighboring meteorological stations) on the real field site to account for water runoff from the uphill large bare area. In the simulation, the infiltrated quantity was imposed and was limited by the maximum

10 infiltration capacity of the soil that is imposed by its permeability at saturation. The computation time step was 15 min and the water mass balance error remained below $0.2 \%$.

In our 2D model, we represented three distinct infiltration scenarios are found for the cover layer in the 2D model zones (Fig. 2abc). The first zone (Western zone) represents a dry cover layer (water content of 0.15) above wet waste material (water content of 0.25$)$. The infiltrated quantity of water $\left(14.4 \mathrm{l} / \mathrm{m}^{2}\right.$ in 2 hours' time) is limited by the permeability of the cover layer

$15\left(2.10^{-6} \mathrm{~m} / \mathrm{s}\right)$. The second zone (central zone) is characterized by the same initial water content, but a larger permeability $\left(10^{-5}\right.$ $\mathrm{m} / \mathrm{s}$ ). The infiltrated quantity of water is $72 \mathrm{l} / \mathrm{m}^{2}$ in 2 hours' time. The last zone (Eastern zone) is a humid cover layer (0.3 water content) above wet waste material, with the same permeability characteristics as in the first zone.

We converted the water content before and after the infiltration event into electrical resistivity (Fig. 2d), using the temperature and pore fluid resistivity distribution and the calibrated Archie's and Campbell's petrophysical laws (Eq. (5-6)). We used the forward modelling code CRTomo (Kemna, 2000) to generate two virtual ERT data sets with the same vertical cell size as used for the simulation of the water dynamics with Hydrus. Noise was added to both data, based on field measured reciprocal errors. The standard deviation is half the measured noise on reciprocal field data, so that $95 \%$ of the simulated data errors are contained with the envelope error model used for data inversion (section 2.2.). Finally, the resistivity distribution and change obtained after the inversion process was converted into water content and compared to the infiltrated water distribution initially computed with Hydrus2D.

In order to investigate the effect of electrode spacing on the resolution of the structures and phenomena under consideration, we generated ERT data for two electrode arrays: $0.5 \mathrm{~m}$ (grid size $0.125 \mathrm{~m}$ for inversion) and $2.5 \mathrm{~m}$ (grid size $0.5 \mathrm{~m}$ for inversion).

\section{The latter corresponds to the spacing we applied in our field experiment.}

30 Two background timeframes ( 2 and 1 hours before the rainfall event) were inverted. The average relative difference in bulk resistivity between the two background tomograms was $0.13 \%$. The second background timeframe is used to calculate changes due to the infiltration process. Before the large rainfall event, the electrical resistivity was heterogeneously distributed (Fig. 
Hydrol. Earth Syst. Sci. Discuss., https://doi.org/10.5194/hess-2018-163

Manuscript under review for journal Hydrol. Earth Syst. Sci.

Discussion started: 31 May 2018

(c) Author(s) 2018. CC BY 4.0 License.

3a). Close to the surface, the cover layer was rather resistive in the Western area of the profile, characterized by a coarser grain size and a larger vegetation cover density. The electrical resistivity decreases eastwards, most likely in relation to the increased water content related to smaller vegetation cover density and a smaller grain size (see Figure 3a). The end of the Eastern extremity of the profile was characterized by very low electrical resistivity.

5 The third profile was acquired 1 hour after the end of the rainfall event and compared to the background acquisition (4h between second background and third profile). Figure $3 \mathrm{~b}$ shows the relative changes of resistivity. In the superficial horizon (first $0.5 \mathrm{~m}$ ), three ranges of relative change of resistivity are visible (3b). The Western (vegetated) area is characterized by 20 to $-50 \%$ changes, the central zone by -30 to $-80 \%$ changes and the Eastern zone by -20 to $+10 \%$ changes. Positive changes in the central zone, at $5 \mathrm{~m}$ depth are probably inversion artifacts, often visible under superficial large resistivity changes, as

10 confirmed by our numerical simulations (Figure 5). The higher changes in the vegetated area might be accounted for by multiple factors such as vegetation, which affects the runoff, the infiltration process and the soil structure, and the heterogeneous initial water content.

The qualitative and quantitative interpretation of the field results in terms of water content changes is challenging for the following reasons. Firstly, in this study, the electrode array ( $2.5 \mathrm{~m}$ spacing) was initially designed to monitor water recirculation

15 experiments, and was therefore less adapted to monitor fine structures and infiltration fronts. The geophysical survey design resulted in ERT profiles characterized by a poor spatial resolution. Therefore, it is unclear whether the thickness of the resistive cover layer observed in the electrical resistivity profile and the depth of the infiltration front observed in resistivity changes profile are real or results from a lack of spatial resolution. Secondly, the relative change of resistivity (Fig. 3b) and the initial resistivity (Fig. 3a) distribution are clearly correlated. A part of the relative change of resistivity signal results from the

20 heterogeneous initial conditions and not the actual water content changes. To overcome this issue, the water content (and absolute water content changes between two time steps) can be computed from the electrical resistivity using the Eq. (5-6). Thirdly, the distribution of physical parameters (water content, pore fluid salinity and temperature) at the initial state strongly influences the quantification of water content changes. Uncertainties in the temperature and pore fluid resistivity values affect the accuracy of the water content assessment (e.g. Brunet et al., 2010).

25 Finally, dilution and cooling effects resulting from cold and fresh water infiltration are difficult to take into account. When computing water content changes from time lapse resistivity data, we generally assume that the infiltrated quantity of water is small enough, or the electrical and temperature properties of the pore fluid and the infiltrating water are not too different, to neglect any change of temperature and salinity in the underground. However, during a large rainfall event in the summer time, the infiltration of cold fresh water likely modifies the pore fluid resistivity. While the temperature changes are small and can

30 generally be neglected, the rain water is more resistive than the pore water and the fluid electrical resistivity increases due to dilution of the TDS immediately after the event and above the infiltration front. 
Hydrol. Earth Syst. Sci. Discuss., https://doi.org/10.5194/hess-2018-163

Manuscript under review for journal Hydrol. Earth Syst. Sci.

Discussion started: 31 May 2018

(c) Author(s) 2018. CC BY 4.0 License.

\section{Virtual experiment}

In the following sections, "we used synthetic case studies to investigate the interpretation of ERT data of a field infiltration phenomenon. The first one is a simple humid sand volume in which fresh and cold water is added. This simple case served to illustrate the effects of several state variables and parameters (the added water quantity, the initial soil water content, the initial

5 pore fluid resistivity and the initial soil temperature) on the resistivity changes. The second case study consists in an unsaturated water flow model combined with ERT data simulation and inversion to understand how the information derived from inverted resistivity data set might differ from the reference infiltration model and how the above-mentioned interpretation limitations (described at section 3.3.) actually hinder quantitative and qualitative analysis of resistivity changes" (Dumont et al., 2017).

\subsection{Local sensitivity analysis on the origin of electrical resistivity changes}

10 In the literature, the relative change of electrical resistivity is commonly used to interpret water content variations in the unsaturated zone (Eq. (1)). Nevertheless, performing a quantitative interpretation is challenging as multiple phenomena may explain the relative changes of the resistivity signal: the added quantity of water, but also the initial water content, the temperature and electrical resistivity contrast between the pore fluid and the added water.

To illustrate this, we set up a synthetic sensitivity analysis in which we added 301 of fresh water $\left(15^{\circ} \mathrm{C}, 1000 \mu \mathrm{S} / \mathrm{cm}\right.$, or 10

$15 \Omega . \mathrm{m}$, at $\left.20^{\circ} \mathrm{C}\right)$ to one cubic meter of sandy soil with an initial volumetric water content of $0.1\left(20^{\circ} \mathrm{C}\right.$, porosity of $40 \%, 8500$ $\mu \mathrm{S} / \mathrm{cm}$, or $1.18 \Omega . \mathrm{m}$, at $\left.20^{\circ} \mathrm{C}\right)$. The heat capacities of water $(4.182 \mathrm{Jg}-1 \mathrm{~K}-1)$ and sand $(0.8 \mathrm{Jg}-1 \mathrm{~K}-1)$ were used for the computation of the new temperature equilibrium. The changes were computed once while taking into account and once while neglecting the salinity dilution effect. The values in the text correspond to the case with dilution effect (red curves in Fig. 4). The bulk resistivity at the initial state, computed with the Archie's and Campbell's laws (Eq. (5-6)), was $226.6 \Omega . m$ and the

20 bulk resistivity at the final state was $161.9 \Omega$.m, so that the relative change of electrical resistivity was $-28.5 \%$. Figure. 4 shows the effect of the different changing state variables while keeping the others constant (the reference situation is highlighted by dotted lines). Since the experiment started with a relatively dry medium, the added quantity of water has a large impact on the electrical resistivity (Fig. 4a), as it corresponds to the humidity ratio to the power $m$ (Eq. (5)). Similarly, the initial quantity of water influences the relative change of electrical resistivity (Fig. 4b). This effect is expected since relative changes are normalized by initial water content. However, the impact of initial water content is generally not discussed while interpreting the results. The initial pore fluid electrical resistivity influences the results as well. When the initial pore fluid electrical resistivity is much lower than the fresh water electrical resistivity, a dilution of the pore fluid resistivity counterbalances the increase of water content (Fig. 4c). The change of temperature has a much smaller influence (Fig. 4d), because temperature varies over a much smaller range than the pore fluid electrical resistivity in this case. In the case of fresh water infiltration,

30 when the dilution effect is neglected (yellow curves on Fig. 4), the computed infiltrated water (from relative resistivity changes) is always underestimated (Fig. 4a). 
Hydrol. Earth Syst. Sci. Discuss., https://doi.org/10.5194/hess-2018-163

Manuscript under review for journal Hydrol. Earth Syst. Sci.

Discussion started: 31 May 2018

Hydrology and

Earth System

(C) Author(s) 2018. CC BY 4.0 License.

Sciences

Discussions

(c) (i)

\subsection{Water infiltration model}

We set up a simplified, 2D unsaturated water flow model for the rainfall event using HYDRUS-2D, representing the different soil water content and permeability conditions encountered on the field (Fig. 2a). Water content data are converted into electrical resistivity data using Eq. (5-6). ERT data are simulated, noise is added and the data are then inverted with two different electrode spacings (Fig. 5). Inverted resistivity distributions are then again converted into water content data. Figure 6a to c compare the vertical water content profile (see location on Fig. 6) for each of the three zones of the 2D section before and after infiltration.

\subsubsection{Effect of resolution}

10 It is widely known that electrode spacing is a key parameter influencing the depth of investigation and the resolution of the inverted profiles. An inappropriate spacing leads to smoothed electrical resistivity distributions that fail to characterize water content changes. As discussed in the literature for a long time, survey design is essential to obtain reliable results. For decades ago, Oldenburg (1978) already studied the optimal electrode spacing to maximize the sensitivity at a given depth. However, the quantification of errors possibly resulting from the lack of spatial resolution is difficult unless with synthetic data. As

15 expected, the water content distribution and changes with the small electrode spacing are better retrieved than with the large electrode spacing. For the 0.5 m electrode spacing (Fig. $6 \mathrm{~d}$ to f; Fig. $5 \mathrm{c}$; Table 2), the transition between the cover layer and the waste material is clearly visible, but at a larger depth $(1.5-2 \mathrm{~m})$ than in the reference model $(1 \mathrm{~m})$. The infiltration front depth is overestimated and smoothed. Under the coarse grain size area (Fig. 6e), the infiltration front is twice too deep $(<1 \mathrm{~m})$ and followed by an important resistivity / water content changes inversion artifact (Fig. $5 \mathrm{~b}$ and d). The $2.5 \mathrm{~m}$ electrode spacing

20 protocol is identical to the acquisition protocol of the real field data. Inverted tomographies result in consistent but smoothed resistivity distributions (Fig. 5 e). A strong inversion artifact appears under the central zone in the relative resistivity changes section (Fig. 5 f). The computed absolute water content change is not correctly evaluated. It is negative in the western area, largely underestimated in the central zone and close to zero in the Eastern area (Fig. 6 g to i; Fig. 5 h; Table 2).

We can conclude that low resolution investigations are not sensitive to small water content changes $\left(14.21 / \mathrm{m}^{2}\right.$ infiltration) and underestimate changes in moderate water infiltration zone $\left(721 / \mathrm{m}^{2}\right)$. The investigation of the resolution issue with numerical modeling shows that the lack of resolution does not account for the thick cover layer and infiltration front observed in our field data.

For the following discussion of the other limitations, we only consider the high resolution case $(0.5 \mathrm{~m}$ electrode spacing).

\subsubsection{Effect of the initial resistivity distribution}

30 In our virtual experiment, the observed relative changes depend both on the initial resistivity distribution and on the effective changes occurring during the infiltration event. E.g. the relative resistivity changes in the initially dry fine grain size area are 
Hydrol. Earth Syst. Sci. Discuss., https://doi.org/10.5194/hess-2018-163

Manuscript under review for journal Hydrol. Earth Syst. Sci.

Discussion started: 31 May 2018

(c) Author(s) 2018. CC BY 4.0 License.

twice as large as the relative resistivity change in the initially wet fine grain size area (Fig. 5 b), while the infiltrated quantity is equivalent (Fig. 5 d). To overcome this interpretation issue, one can compute the water content distribution (and the change of water content distribution), provided the pore fluid resistivity and temperature are known (which is the case for this synthetic model), using the Eq. (5-6). As a first step, the cooling and dilution effect resulting from fresh cold water infiltration is not considered.

For this perfectly known and well-resolved synthetic case, the distribution of absolute water content changes is correctly retrieved (Fig. 5 d). The infiltrated quantity of water (area between the two water distribution curves) is close to the imposed value (Table 2). The total infiltration is five times higher in the coarse area than in the fine one, as imposed in the model. However, relative water content changes are much higher in the initially dry area than in the initially wet area, whereas the

10 actual infiltration pattern is identical. Obviously, this observation results from the initial water content state and not the infiltrated quantity. This is a known and trivial phenomenon, but is very rarely considered when interpreting time lapse data and shows the advantage of working in absolute changes. When the changes distribution is discussed alone (and the initial resistivity distribution is not even displayed), the use of specific thresholds of relative change of water content (or resistivity) to locate high and low infiltration zone could be misleading.

\section{4.2.3 Effect of environmental state variables on the water content computation}

While the relative changes (and not the absolute changes) are influenced by the background heterogeneities, the absolute changes of water content are affected by the uncertainty on the initial temperature and the pore fluid resistivity. The conversion of electrical resistivity to water content requires the knowledge of these environmental input data whose uncertainty propagates in the water content and change of water content computation.

20 From Eq. (8), an error of $10 \%$ in temperature (around $20^{\circ} \mathrm{C}$ ) would result in a $-1.8 \%$ relative error in water content estimation. On the field site, the temperature of the cover layer was about $25^{\circ} \mathrm{C}$. A $25 \%$ temperature $\left(20-31^{\circ} \mathrm{C}\right.$ instead of $\left.25^{\circ} \mathrm{C}\right)$ uncertainty results in a $5 \%$ water content uncertainty, which is the smallest encountered uncertainty in the interpretation process.

From Eq. (9), an error of $10 \%$ in pore fluid resistivity results in a $4.8 \%$ relative error in water content. Thus, the uncertainty on the pore fluid resistivity leads the larger uncertainty on the water content estimation. Moreover, the cover layer initial pore fluid resistivity typically varies over more than one order of magnitude in a landfill (0.9-10 $\Omega . m)$, resulting in a large uncertainty on the computed absolute water content and changes. For a given bulk resistivity, a small pore water resistivity is associated to a small water content. Therefore, a small additional amount of water is needed to induce the observed resistivity changes. If the pore fluid resistivity $\rho_{w, T_{-} r e f}$ doubles, the computed change of water content is multiplied by $\sqrt[m]{2}$. For the synthetic models, the pore fluid resistivity considered for the cover layer is 1.39 $\Omega . m$ (average over the cover layer). If extreme

30 values shown for the cover layer are used for the interpretation $(0.9-10 \Omega . \mathrm{m})$, while $1.39 \Omega . \mathrm{m}$ is the correct value, the computed water content value would be respectively 2.5 times overestimated or 1.23 times underestimated. 
Hydrol. Earth Syst. Sci. Discuss., https://doi.org/10.5194/hess-2018-163

Manuscript under review for journal Hydrol. Earth Syst. Sci.

Discussion started: 31 May 2018

Hydrology and

Earth System

(C) Author(s) 2018. CC BY 4.0 License.

Sciences

Discussions

(c) (i)

\subsubsection{Discrimination between water content changes, dilution of pore water and cooling during infiltration}

The local sensitivity analysis during fresh water infiltration (section 4.1.) shows that the temperature changes effects on the interpretation of the infiltration process are negligible. However, "given the contrast between the initial pore fluid resistivity

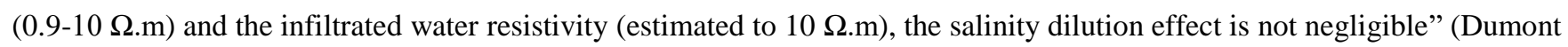

5 et al., 2017). There are several approaches to solve this issue. One can try to monitor the temperature and pore fluid resistivity at several locations during the infiltration process (e.g. Fernandez de Vera et al., 2015). However, these measurements are generally local and may be more difficult to obtain than direct water content measurements (with TDR for instance). Others

will couple the ERT and hydrological model interpretation. However, this approach necessitates numerous input data for the ground water flow model that are difficult to obtain (Hermans et al., 2012; Kemna et al., 2002). The implementation of fully

10 coupled hydrogeophysical models, eventually including solute transport, together with the use of groundtruth measurements, might help addressing this issue in future studies (Binley et al., 2015, 2010).

To illustrate the dilution effect in this study, "we conducted three simulations with the same infiltrated quantity of water (72mm in the coarse grain size area), but distinct hypotheses for the dilution effect" (Dumont et al., 2017) (Fig. 7b). Firstly, no dilution is simulated. Secondly, a new salinity equilibrium is computed for every depth slice, given the initial water content and the

15 added quantity of fresh water. Thirdly, a salinity increase with depth is considered between the surface (electrical resistivity close to rain water resistivity) and the bottom of the infiltration front (initial electrical resistivity), the total mass of salt being conserved. Given the relation between the pore fluid conductivity and the TDS, pore fluid electrical conductivity (instead of resistivity) are presented in Fig. $7 \mathrm{~b}$.

"Thereafter, ERT data are simulated (with the $0.5 \mathrm{~m}$ electrode spacing). Inverted resistivity data are converted into water

20 content while considering a $7200 \mu \mathrm{S} / \mathrm{cm}$ pore fluid conductivity (1.39 $\Omega . \mathrm{m}$ resistivity). By doing this, the dilution effect is simulated in the model, but neglected in the interpretation" (Dumont et al., 2017) (Fig. 7a). The simulated infiltrated quantity is $72 \mathrm{~mm}$, while the estimated quantities are $38 \mathrm{~mm}$ and $24 \mathrm{~mm}$ if dilution is neglected in the interpretation and $72 \mathrm{~mm}$ and $66 \mathrm{~mm}$ if dilution is considered. The computed infiltrated quantity while neglecting the dilution effect was twice as low. The more conductive the initial pore fluid (and the lower the initial water content for a given bulk resistivity), the larger the dilution effect and the misinterpretation.

\section{Discussion}

The numerical simulations allow us to interpret the field data without over-interpreting the results. An important zone of the studied profile is the central zone with coarse grain sizes, where the majority of the infiltration occurred. The maximum relative resistivity change observed is $-86 \%$ (Fig. 3). If the water content after the large infiltration process is close to saturation (0.4),

30 the initial water content should have been about 0.15 if dilution is neglected (Eq. (5)).

Given that in the field data, the initial bulk resistivity in this central zone is about $200 \Omega$.m (Fig. 3b), for a 0.15 water content, the pore fluid resistivity in that area is about $2.5 \Omega . \mathrm{m}$ (Eq. (5)). We consider these values and model a series of synthetic cases 
Hydrol. Earth Syst. Sci. Discuss., https://doi.org/10.5194/hess-2018-163

Manuscript under review for journal Hydrol. Earth Syst. Sci.

Discussion started: 31 May 2018

(c) Author(s) 2018. CC BY 4.0 License.

with different cover layer thickness ( 1 to $2.5 \mathrm{~m}$ ) and infiltrated water content ( 72 to $504 \mathrm{l} / \mathrm{m}^{2}$ ). We obtain, using modeling, that a $2 \mathrm{~m}$ thick cover layer better correlates with the initial resistivity distribution of the field case. In addition, to obtain a similar magnitude of the observed resistivity changes a similar depth of the infiltration front, the modeling requires a much larger infiltrated quantity $\left(360 \mathrm{l} / \mathrm{m}^{2}\right)$. Such a large infiltrated quantity necessitates a $5 * 10-5 \mathrm{~m} / \mathrm{s}$ permeability for the cover layer and

5 a large amount of water supply resulting from runoff on uphill area. Simulated data are compared qualitatively to field data in Fig. $3 \mathrm{c}$ to d. With these parameters, the cover layer resistivity value and thickness are similarly depicted in the inverted electrical resistivity distribution of simulated data and field data (Fig. 3c). The resistive zone at 6-12 m depth in the center of the latest is not reproduced with the numerical simulation (Fig. 3c), suggesting that the synthetic case is over-simplified with respected to the field conditions. The resistivity relative changes (Fig. 3d) distribution are similar in intensity and thickness for

10 the simulated and field time-lapse observations. A resistivity increase is noticed in both field data and synthetic data under the infiltration front, and is interpreted as an inversion artifact (overshooting artefact).

If the electrical resistivity of this water arrival strongly differs from the pore fluid resistivity in the cover layer, then the changes of water content are underestimated (while neglecting the dilution effect), the initial water content is lower than 0.15 and the pore fluid resistivity at the initial state lower than $2.5 \Omega$. m. The neglected dilution effect is still more important than initially assumed.

\section{Conclusion}

Our primary objective in this study was to use time-lapse ERT to investigate the effect of a major rainfall event on water infiltration in a landfill. In the context of large scale landfill investigation, we highlighted some interpretation pitfalls related to the study design, or related to the field site initial conditions (heterogeneous water content distribution). Synthetic

20 experiments were used to offer a better understanding of these interpretation limitations. The modelling of water dynamics in the vadose zone and subsequent simulation of ERT data for two distinct electrode spacings $(0.5$ and $2.5 \mathrm{~m})$ highlights these limitations. Firstly, we confirm that the ability of ERT to detect small changes strongly depends on the survey design (notably the electrode spacing). The $2.5 \mathrm{~m}$ electrode spacing, chosen for the large scale investigation of a landfill, results in poor resolution ERT images that fail to represent in details the infiltration dynamics due to the bias introduced by the inadequate

25 resolution and the inherent smoothing of the tomogram. Indeed, preliminary investigation of such large deposit sites can hardly be conducted with decimeter electrode spacing at a reasonable cost. Nevertheless, a $0.5 \mathrm{~m}$ spacing, as used by Genelle et al., (2012) for cover layer characterization, would have been more appropriate for infiltration monitoring. Low resolution numerical simulations resulted in an underestimation or even a non-detection of the infiltration. Therefore, another explanation has to be found for the thick cover layer and thick infiltration front observed in our field data. Secondly, the interpretation of

30 relative resistivity changes might be misleading, as this parameter reflects both the initial water content distribution and the changes of water content. This issue is trivial for well resolved studies, but also persists for low resolution investigation. For our field case, the imaged relative changes are correlated to the initial resistivity distribution. Thirdly, for the quantitative 
Hydrol. Earth Syst. Sci. Discuss., https://doi.org/10.5194/hess-2018-163

Manuscript under review for journal Hydrol. Earth Syst. Sci.

Discussion started: 31 May 2018

(c) Author(s) 2018. CC BY 4.0 License.

(c) (i)

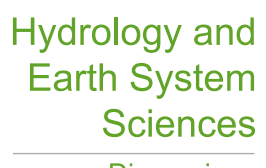

Discussions

interpretation of water content and water content changes, the computed values depend on the assumption with regard to the pore fluid resistivity and temperature (even for perfectly resolved studies). These values are difficult to estimate in field applications where the distribution is strongly heterogeneous. However, this approach is more feasible for regular soil water content studies (e.g. Jayawickreme et al., 2008). Moreover, an effective conversion from electrical resistivity to water content can only be performed if the resistivity distribution is fully depicted by a high resolution tomography. The exact same conclusions can be drawn for the water mass balance during a water tracer test (Binley et al., 2002a) or the salt mass balance during saline tracer test (e.g. Day-Lewis et al., 2005). Fourthly, fresh water infiltration in a landfill cover layer naturally results in a soil temperature and a pore fluid salinity decrease due to dilution of the native pore water with fresh, less saline infiltration water. In the literature, the latest is very often not considered while interpreting resistivity changes. Unfortunately, neglecting theseis dilution effect leads to an underestimation of the total water content after rainfall.

In our field case, although the fine details of infiltration are not retrieved, low resolution ERT allows to investigate the cover layer in landfills in a preliminary stage of a monitoring study. This study shows that the acquisition of background profiles and their comparison with the profile acquired after rainfall successfully highlighted variations in electrical resistivity which are interpreted as water content changes. These data allow the identification of zones where a large infiltration surely occurred, but offers no quantification of the infiltrated water volume due to the large uncertainty on pore water resitivity and possible dilution effect. Nevertheless, the detection and mapping of the main infiltration zones is a useful tool to understand the water dynamics in the landfill. It helps to regulate its management, as these zones are typically responsible for a large percentage of the annual cumulated infiltration inside the landfill and there is a real interest for higher gas emission through the capping (e.g. Robertson and Dunbar, 2005).

\section{Acknowledgements}

The MINERVE project is a multidisciplinary research program financed by the Walloon Region (Plan Marshall2.vert, pôle GreenWin; http://greenwinminerve.com/). We are grateful to SHANKS, the leader of the research program, for the access to the site and technical support. 
Hydrol. Earth Syst. Sci. Discuss., https://doi.org/10.5194/hess-2018-163

Manuscript under review for journal Hydrol. Earth Syst. Sci.

Discussion started: 31 May 2018

(c) Author(s) 2018. CC BY 4.0 License.

\section{References}

Albright, W. H., Benson, C. H., Gee, G. W., Roesler, A. C., Abichou, T., Apiwantragoon, P., Lyles, B. F. and Rock, S. A.: Field water balance of landfill final covers, J. Environ. Qual., 33(6), 2317-2332, 2004.

5 Archie, G. E.: The electrical resistivity $\log$ as an aid in determining some reservoir characteristics, Trans. Am. Inst. Min. Metall. Pet. Eng., 146, 54-67, 1942.

Audebert, M., Clément, R., Grossin-Debattista, J., Günther, T., Touze-Foltz, N. and Moreau, S.: Influence of the geomembrane on time-lapse ERT measurements for leachate injection monitoring, Waste Manag., 34(4), 780-790, doi:10.1016/j.wasman.2014.01.011, 2014.

10 Audebert, M., Clément, R., Moreau, S., Duquennoi, C., Loisel, S. and Touze-Foltz, N.: Understanding leachate flow in municipal solid waste landfills by combining time-lapse ERT and subsurface flow modelling - Part I: Analysis of infiltration shape on two different waste deposit cells, Waste Manag., doi:10.1016/j.wasman.2016.04.006, 2016a.

Audebert, M., Oxarango, L., Duquennoi, C., Touze-Foltz, N., Forquet, N. and Clément, R.: Understanding leachate flow in municipal solid waste landfills by combining time-lapse ERT and subsurface flow modelling - Part II: Constraint methodology

15 of hydrodynamic models, Waste Manag., doi:10.1016/j.wasman.2016.04.005, 2016 b.

Auken, E., Doetsch, J., Fiandaca, G., Christiansen, A. V., Gazoty, A., Cahill, A. G. and Jakobsen, R.: Imaging subsurface migration of dissolved CO2 in a shallow aquifer using 3-D time-lapse electrical resistivity tomography, J. Appl. Geophys., 101, 31-41, doi:10.1016/j.jappgeo.2013.11.011, 2014.

Beff, L., Günther, T., Vandoorne, B., Couvreur, V. and Javaux, M.: Three-dimensional monitoring of soil water content in a

20 maize field using Electrical Resistivity Tomography, Hydrol. Earth Syst. Sci., 17(2), 595-609, doi:10.5194/hess-17-595-2013, 2013.

Binley, A., Winship, P., West, L. J., Pokar, M. and Middleton, R.: Seasonal variation of moisture content in unsaturated sandstone inferred from borehole radar and resistivity profiles, J. Hydrol., 267(3), 160-172, 2002a.

Binley, A., Cassiani, G., Middleton, R. and Winship, P.: Vadose zone flow model parameterisation using cross-borehole radar and resistivity imaging, J. Hydrol., 267(3), 147-159, $2002 \mathrm{~b}$.

Binley, A., Cassiani, G. and Deiana, R.: Hydrogeophysics: opportunities and challenges, Boll. Geofis. Teor. Ed Appl., 51(4), 267-284, 2010.

Binley, A., Hubbard, S. S., Huisman, J. A., Revil, A., Robinson, D. A., Singha, K. and Slater, L. D.: The emergence of hydrogeophysics for improved understanding of subsurface processes over multiple scales, Water Resour. Res., 51(6), 3837-

30 3866, doi:10.1002/2015WR017016, 2015.

Brunet, P., Clément, R. and Bouvier, C.: Monitoring soil water content and deficit using Electrical Resistivity Tomography (ERT) - A case study in the Cevennes area, France, J. Hydrol., 380(1-2), 146-153, doi:10.1016/j.jhydrol.2009.10.032, 2010. 
Hydrol. Earth Syst. Sci. Discuss., https://doi.org/10.5194/hess-2018-163

Manuscript under review for journal Hydrol. Earth Syst. Sci.

Discussion started: 31 May 2018

(c) Author(s) 2018. CC BY 4.0 License.

Campbell, R., Bower, C. and Richards, L.: Change of electrical conductivity with temperature and the relation of osmotic pressure to electrical conductivity and ion concentration in soil extracts, Soil Sci. Soc. Am. Proc., 13, 66-69, 1948.

Clément, R., Descloitres, M., Günther, T., Oxarango, L., Morra, C., Laurent, J.-P. and Gourc, J.-P.: Improvement of electrical resistivity tomography for leachate injection monitoring, Waste Manag., 30(3), 452-464, doi:10.1016/j.wasman.2009.10.002,

52010.

Clément, R., Oxarango, L. and Descloitres, M.: Contribution of 3-D time-lapse ERT to the study of leachate recirculation in a landfill, Waste Manag., 31(3), 457-467, doi:10.1016/j.wasman.2010.09.005, 2011.

Dahlin, T. and Zhou, B.: Multiple-gradient array measurements for multichannel 2D resistivity imaging, Surf. Geophys., 4(2), 113-123, doi:10.3997/1873-0604.2005037, 2006.

10 Daily, W., Ramirez, A., LaBrecque, D. and Nitao, J.: Electrical resistivity tomography of vadose water movement, Water Resour. Res., 28(5), 1429-1442, doi:10.1029/91WR03087, 1992.

Day-Lewis, F. D., Singha, K. and Binley, A.: Applying petrophysical models to radar travel time and electrical resistivity tomograms: Resolution-dependent limitations, J. Geophys. Res., 110, B08206, doi:10.1029/2004JB003569, 2005.

Doetsch, J., Linde, N., Vogt, T., Binley, A. and Green, A. G.: Imaging and quantifying salt-tracer transport in a riparian 15 groundwater system by means of 3D ERT monitoring, Geophysics, 77(5), B207-B218, doi:10.1190/geo2012-0046.1, 2012. Doetsch, J., Fiandaca, G., Auken, E., Christiansen, A. V., Cahill, A. G. and Jakobsen, R.: Field-scale time-domain spectral induced polarization monitoring of geochemical changes induced by injected $\mathrm{CO} 2$ in a shallow aquifer, GEOPHYSICS, 80(2), WA113-WA126, doi:10.1190/geo2014-0315.1, 2015.

Dumont, G., Pilawski, T., Dzaomuho-Lenieregue, P., Hiligsmann, S., Delvigne, F., Thonart, P., Robert, T., Nguyen, F. and

20 Hermans, T.: Gravimetric water distribution assessment from geoelectrical methods (ERT and EMI) in municipal solid waste landfill, Waste Manag., doi:10.1016/j.wasman.2016.02.013, 2016.

Dumont, G., Pilawski, T., Robert, T., Hermans, T., Garré, S. and Nguyen, F.: The effect of initial water distribution and spatial resolution on the interpretation of ERT monitoring of water infiltration, [online] Available from: https://orbi.uliege.be/handle/2268/213954 (Accessed 2 May 2018), 2017.

25 Fernandez de Vera, N., Dahan, O., Dassargues, A., Vanclooster, M., Nguyen, F. and Brouyère, S.: Vadose zone characterisation at industrial contaminated sites, $\mathrm{CL}$ AIRE Bull. [online] Available from: http://orbi.ulg.ac.be/handle/2268/185699 (Accessed 30 August 2016), 2015.

Garré, S., Günther, T., Diels, J. and Vanderborght, J.: Evaluating Experimental Design of ERT for Soil Moisture Monitoring in Contour Hedgerow Intercropping Systems, Vadose Zone J., 11(4), 0, doi:10.2136/vzj2011.0186, 2012.

30 Garré, S., Coteur, I., Wongleecharoen, C., Kongkaew, T., Diels, J. and Vanderborght, J.: Noninvasive Monitoring of Soil Water Dynamics in Mixed Cropping Systems: A Case Study in Ratchaburi Province, Thailand, Vadose Zone J., 12(2), 0, doi:10.2136/vzj2012.0129, 2013.

Genelle, F., Sirieix, C., Riss, J. and Naudet, V.: Monitoring landfill cover by electrical resistivity tomography on an experimental site, Eng. Geol., 145-146, 18-29, doi:10.1016/j.enggeo.2012.06.002, 2012. 
Hydrol. Earth Syst. Sci. Discuss., https://doi.org/10.5194/hess-2018-163

Manuscript under review for journal Hydrol. Earth Syst. Sci.

Discussion started: 31 May 2018

Hydrology and

Earth System

Sciences

(c) Author(s) 2018. CC BY 4.0 License.

Discussions

(c) (i)

van Genuchten, M. T.: A closed form equation for predicting the hydraulic conductivity of unsaturated soils, Soil Sci Soc Am J, 44, 892-898, 1980.

Grellier, S., Reddy, K., Gangathulasi, J., Adib, R. and Peters, A.: Electrical Resistivity Tomography Imaging of Leachate Recirculation in Orchard Hills Landfill, in Proceedings of the SWANA Conference, Charlotte, 2006.

5 Grellier, S., Reddy, K., Gangathulasi, J., Adib, R. and Peters, C.: Correlation between Electrical Resistivity and Moisture Content of Municipal Solid Waste in Bioreactor Landfill, Geotech. Spec. Publ., (163), 1-14, 2007.

Grellier, S., Guérin, R., Robain, H., Bobachev, A., Vermeersch, F. and Tabbagh, A.: Monitoring of leachate recirculation in a bioreactor landfill by 2-D electrical resistivity imaging, J. Environ. Eng. Geophys., 13(4), 351-359, 2008.

de Groot-Hedlin, C. D. and Constable, S. C.: Occam's inversion to generate smooth, two-dimensional models from

10 magnetotelluric data, Geophysics, 55(12), 1613-1624, doi:10.1190/1.1442813, 1990.

Guérin, R., Munoz, M. L., Aran, C., Laperrelle, C., Hidra, M., Drouart, E. and Grellier, S.: Leachate recirculation: moisture content assessment by means of a geophysical technique, Waste Manag., 24(8), 785-794, doi:10.1016/j.wasman.2004.03.010, 2004.

Hermans, T., Vandenbohede, A., Lebbe, L. and Nguyen, F.: A shallow geothermal experiment in a sandy aquifer monitored

15 using electric resistivity tomography, Geophysics, 77, B11-B21, 2012.

Hermans, T., Wildemeersch, S., Jamin, P., Orban, P., Brouyère, S., Dassargues, A. and Nguyen, F.: Quantitative temperature monitoring of a heat tracing experiment using cross-borehole ERT, Geothermics, 53, 14-26, doi:10.1016/j.geothermics.2014.03.013, 2015.

Imhoff, P., Reinhart, D., Englund, M., Guérin, R., Gawande, N., Han, B., Jonnalagadda, S., Townsend, T. and Yazdani, R.:

20 Review of state of the art methods for measuring water in landfills, Waste Manag., 27(6), 729-745, doi:10.1016/j.wasman.2006.03.024, 2007.

Jayawickreme, D. H., Van Dam, R. L. and Hyndman, D. W.: Subsurface imaging of vegetation, climate, and root-zone moisture interactions, Geophys. Res. Lett., 35(18), doi:10.1029/2008GL034690, 2008.

Kemna, A.: Tomographic Inversion of Complex Resistivity-Theory and Application, Ruhr-Universität, Bochum, Germany., 2000.

Kemna, A., Kulessa, B. and Vereecken, H.: Imaging and characterisation of subsurface solute transport using electrical resistivity tomography (ERT) and equivalent transport models, J. Hydrol., 267(3), 125-146, 2002.

Koestel, J., Kemna, A., Javaux, M., Binley, A. and Vereecken, H.: Quantitative imaging of solute transport in an unsaturated and undisturbed soil monolith with 3-D ERT and TDR, Water Resour. Res., 44(12), W12411, doi:10.1029/2007WR006755, 302008.

LaBrecque, D. J. and Yang, X.: Difference Inversion of ERT Data: a Fast Inversion Method for 3-D In Situ Monitoring, J. Environ. Eng. Geophys., 6(2), 83-89, doi:10.4133/JEEG6.2.83, 2001.

Loke, M. H., Chambers, J. E., Rucker, D. F., Kuras, O. and Wilkinson, P. B.: Recent developments in the direct-current geoelectrical imaging method, J. Appl. Geophys., 95, 135-156, doi:10.1016/j.jappgeo.2013.02.017, 2013. 
Hydrol. Earth Syst. Sci. Discuss., https://doi.org/10.5194/hess-2018-163

Manuscript under review for journal Hydrol. Earth Syst. Sci.

Discussion started: 31 May 2018

(c) Author(s) 2018. CC BY 4.0 License.
Hydrology and

Earth System

Sciences

Discussions

Ma, Y., Van Dam, R. L. and Jayawickreme, D. H.: Soil moisture variability in a temperate deciduous forest: insights from electrical resistivity and throughfall data, Environ. Earth Sci., 72(5), 1367-1381, doi:10.1007/s12665-014-3362-y, 2014.

Meju, M.: Geoelectrical characterization of covered landfill sites: a process-oriented model and Investigative approach, in Applied hydrogeophysics, pp. 319-339, Springer., 2006.

5 Miller, C. R., Routh, P. S., Brosten, T. R. and McNamara, J. P.: Application of time-lapse ERT imaging to watershed characterization, Geophysics, 73(3), G7-G17, doi:10.1190/1.2907156, 2008.

Oldenburg, D. W.: The interpretation of direct current resistivity measurements, Geophysics, 43(3), 610-625, doi:10.1190/1.1440840, 1978.

Oldenburg, D. W. and Li, Y.: Subspace linear inverse method, Inverse Probl., 10, 915-935, 1994.

10 Pellet, C., Hilbich, C., Marmy, A. and Hauck, C.: Soil Moisture Data for the Validation of Permafrost Models Using Direct and Indirect Measurement Approaches at Three Alpine Sites, Cryospheric Sci., 91, doi:10.3389/feart.2015.00091, 2016.

Power, C., Gerhard, J. I., Tsourlos, P., Soupios, P., Simyrdanis, K. and Karaoulis, M.: Improved time-lapse electrical resistivity tomography monitoring of dense non-aqueous phase liquids with surface-to-horizontal borehole arrays, J. Appl. Geophys., 112, 1-13, doi:10.1016/j.jappgeo.2014.10.022, 2015.

15 Reinhart, D. R. and Townsend, T. G.: Landfill Bioreactor Design and Operation, Lewis Publishers, Boca Raton., 1997.

Robert, T., Caterina, D., Deceuster, J., Kaufmann, O. and Nguyen, F.: A salt tracer test monitored with surface ERT to detect preferential flow and transport paths in fractured/karstified limestones, Geophysics, 77(2), B55-B67, 2012.

Robertson, T. and Dunbar, J.: Guidance for Evaluating Landfill Gas Emissions from Closed Or Abandoned Facilities, U.S. Environmental Protection Agency, Office of Research and Development., 2005.

20 Šimůnek, J., van Genuchten, M. T. and Šejna, M.: The HYDRUS Software Package for Simulating Two- and Three Dimensional Movement of Water, Heat, and Multiple Solutes in Variably Saturated Porous Media, Version 2.0, Technical Manual, PC Progress, Prague, Czech Republic., 2012.

Slater, L., Binley, A. ., Daily, W. and Johnson, R.: Cross-hole electrical imaging of a controlled saline tracer injection, J. Appl. Geophys., 44(2-3), 85-102, doi:10.1016/S0926-9851(00)00002-1, 2000.

25 Stoltz, G., Tinet, A.-J., Staub, M. J., Oxarango, L. and Gourc, J.-P.: Moisture retention properties of municipal solid waste in relation to compression, J. Geotech. Geoenvironmental Eng., 138(4), 535-543, 2012.

Wyllie, M. R. J. and Gregory, A. R.: Formation Factors of Unconsolidated Porous Media: Influence of Particle Shape and Effect of Cementation, J. Pet. Technol. - J Pet. TECHNOL, 5(4), 103-110, doi:10.2118/223-G, 1953. 
Hydrol. Earth Syst. Sci. Discuss., https://doi.org/10.5194/hess-2018-163

Manuscript under review for journal Hydrol. Earth Syst. Sci.

Discussion started: 31 May 2018

(c) Author(s) 2018. CC BY 4.0 License.
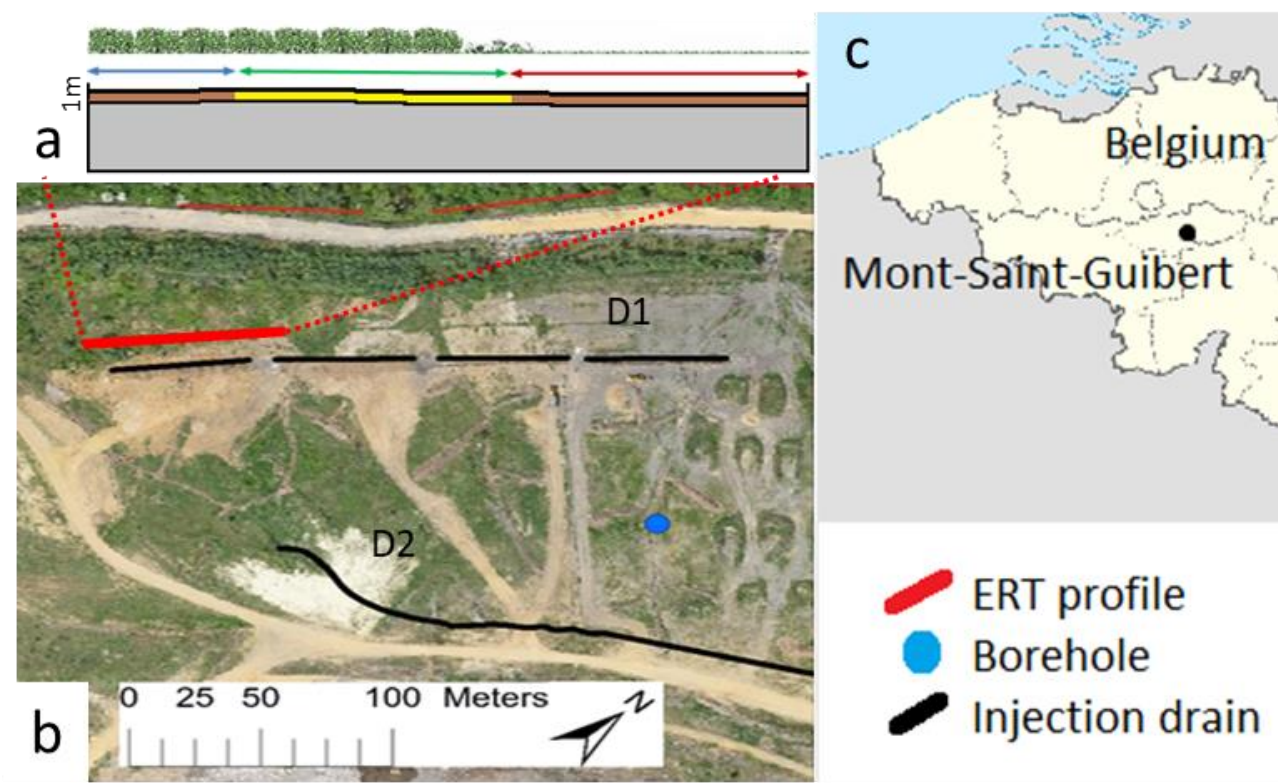

Figure 1: (a) Soil section along ERT line. (b) Mont-Saint-Guibert technical landfill infrastructure. ERT line is depicted in red, borehole in blue and recirculation drains in black (D1 is located uphill, D2 is parrallel to ERT line). The 1m thick cover layer texture is coarse in the centre (yellow) of the profile and fine at both extremities (brown). The SW zone is vegetated. (c) Mont-Saint-Guibert location in Belgium. 
Hydrol. Earth Syst. Sci. Discuss., https://doi.org/10.5194/hess-2018-163

Manuscript under review for journal Hydrol. Earth Syst. Sci.

Discussion started: 31 May 2018

(c) Author(s) 2018. CC BY 4.0 License.
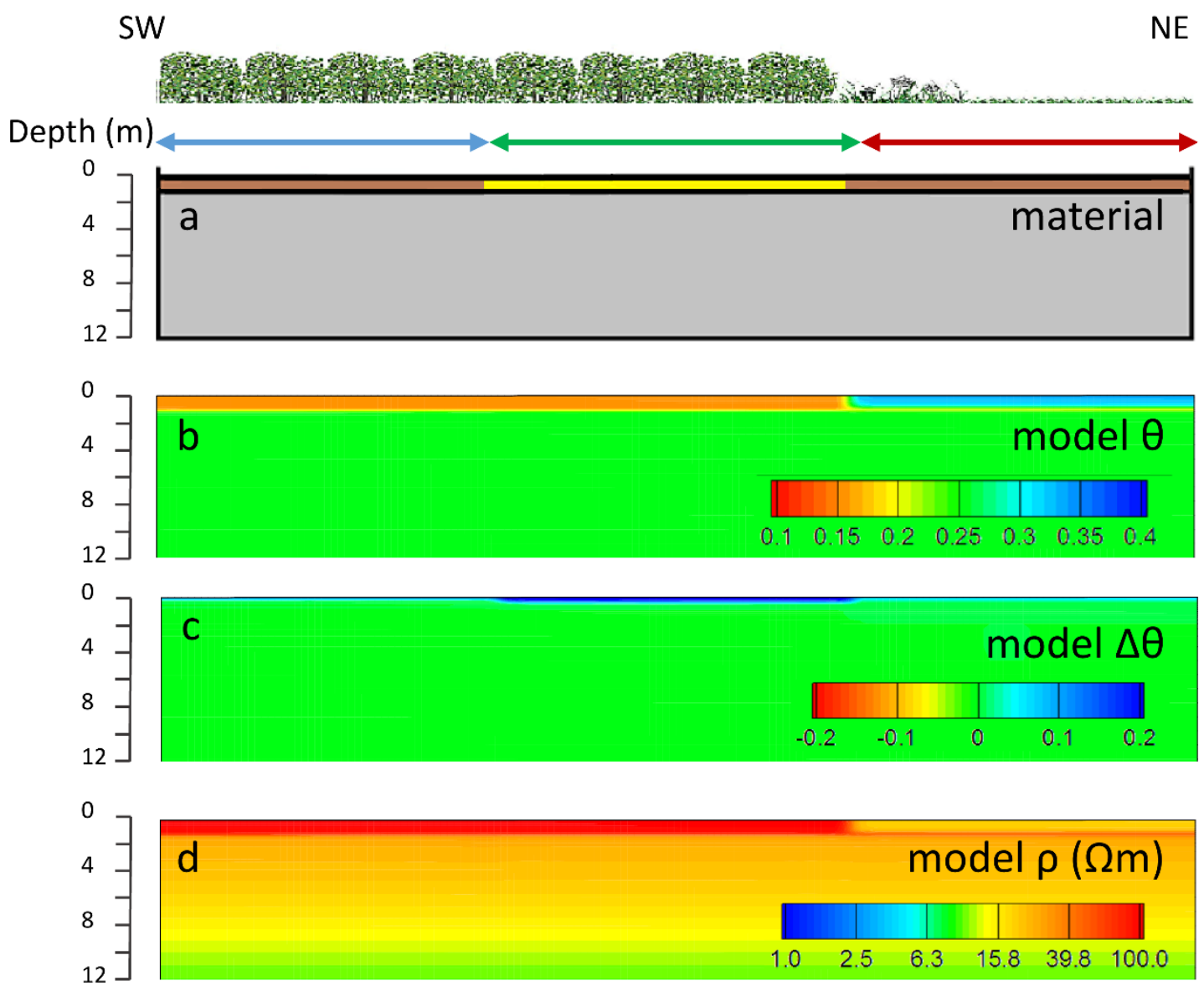

Figure 2: Synthetic modeling of water infiltration: (a) cover layer composition; (b) initial water content; (c) infiltrated water; (d) initial electrical resistivity model.

\begin{tabular}{|l|l|l|l|l|l|l|l|}
\hline \multirow{2}{*}{} & \multicolumn{6}{|c|}{ van Genuchten-Mualem coefficients } & \multirow{2}{*}{ Initial $\theta$} \\
\cline { 2 - 8 } & Qr (-) & Qs (-) & $\alpha\left(\mathrm{m}^{-1}\right)$ & $\mathrm{N}(-)$ & Ks (m/h) & L (-) & \\
\hline Fine cov (bare) & 0.065 & 0.4 & 2 & 1.5 & 0.0072 & 0.5 & 0.33 \\
\hline Fine cov (veg.) & 0.065 & 0.4 & 2 & 1.5 & 0.0072 & 0.5 & 0.15 \\
\hline Coarse cov (veg.) & 0.065 & 0.4 & 2 & 1.5 & 0.036 & 0.5 & 0.15 \\
\hline Waste & 0.15 & 0.5 & 2 & 1.5 & 0.36 & 0.5 & 0.25 \\
\hline
\end{tabular}

Table 1: material coefficients for the van Genuchten-Mualem water retention function and hydraulic conductivity function. $\Theta$ is the 5 volumetric water content, $Q r$ is the water content at retention capacity, $Q$ s is the water content at saturation capacity, $\alpha$ and $n$ control the shape of the hydraulic property curve, $\mathrm{Ks}$ is the saturated hydraulic conductivity and $\mathrm{l}$ is a pore connectivity parameter. 
Hydrol. Earth Syst. Sci. Discuss., https://doi.org/10.5194/hess-2018-163

Manuscript under review for journal Hydrol. Earth Syst. Sci.

Discussion started: 31 May 2018

(c) Author(s) 2018. CC BY 4.0 License.
Hydrology and

(c) (i)

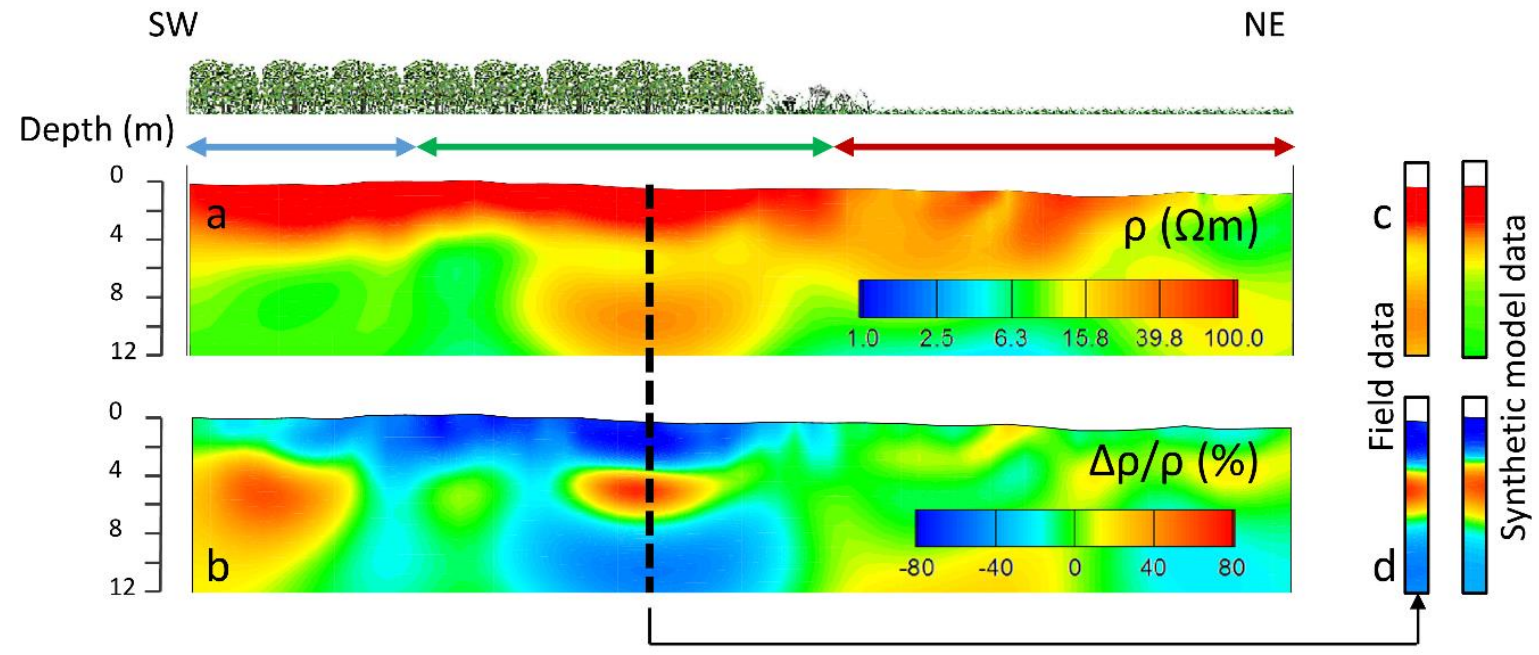

Figure 3: electrical resistivity tomography and changes after the rainfall event: (a) background electrical resistivity; (b) relative change of electrical resistivity; (c) electrical resistivity comparison between field data and synthetic data; (d) relative change of electrical resistivity comparison between field data and synthetic data (modified from Dumont et al., 2017).

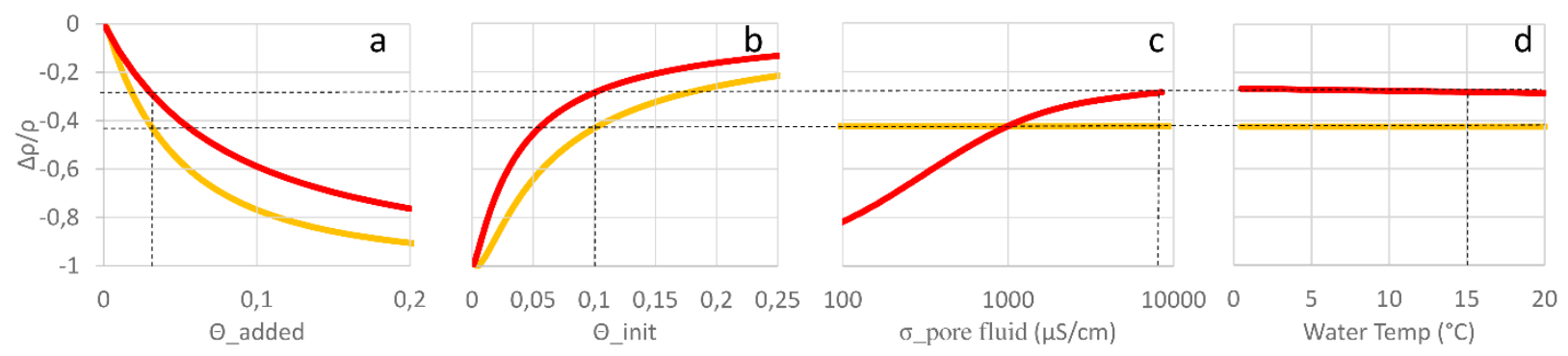

Figure 4: effect of various parameters on the relative changes of electrical resistivity: (a) added water quantity; (b) initial water content; (c) initial pore fluid conductivity; (d) infiltrated water temperature. The salinity dilution effect is considered for the yellow curves and neglected for the red curves. Dashed lines represent the reference situation (from Dumont et al., 2017). 
Hydrol. Earth Syst. Sci. Discuss., https://doi.org/10.5194/hess-2018-163

Manuscript under review for journal Hydrol. Earth Syst. Sci.

Discussion started: 31 May 2018

(c) Author(s) 2018. CC BY 4.0 License.
Hydrology and

Earth System Sciences

Discussions

(c) (i)

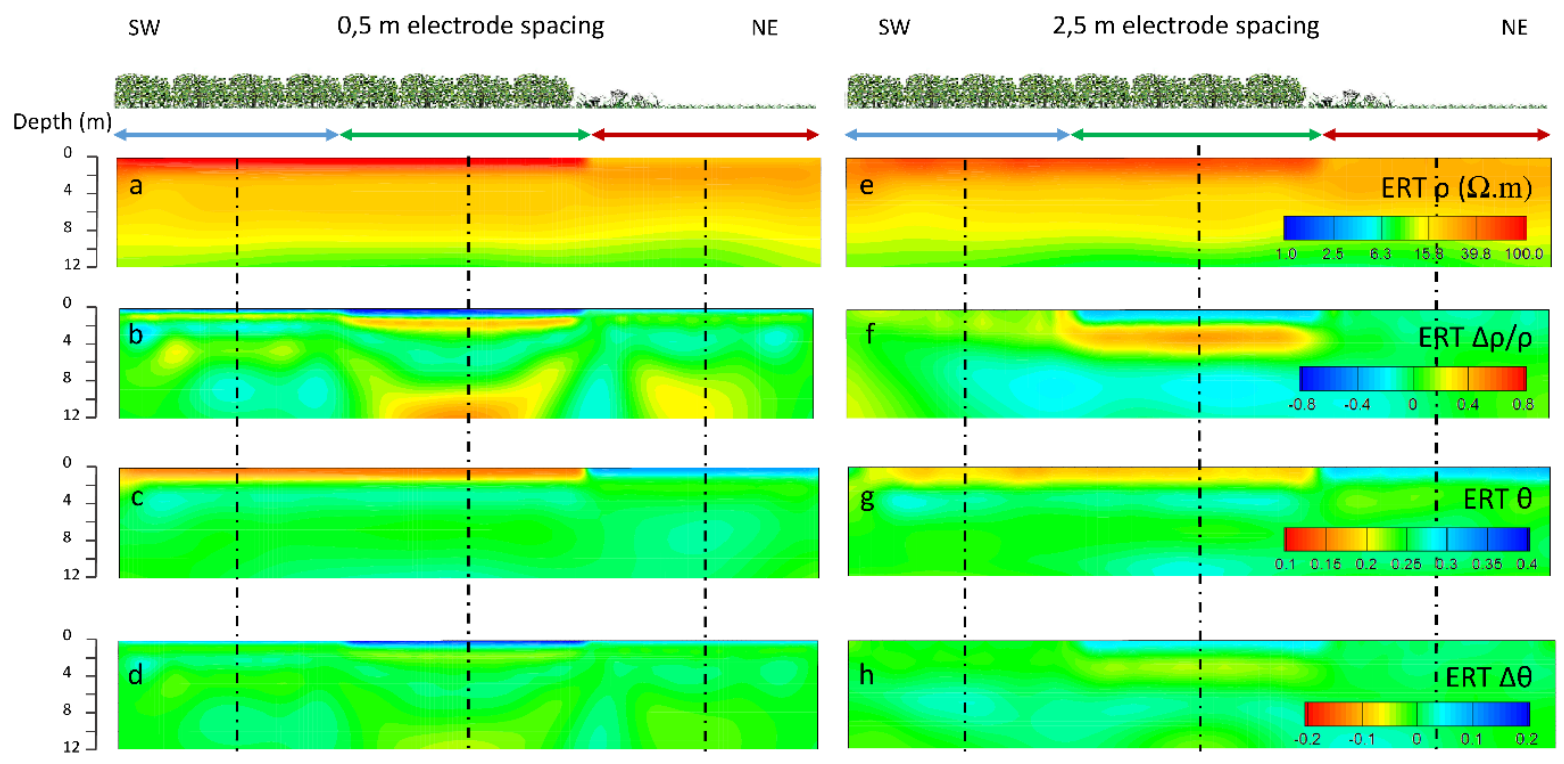

Figure 5 : numerical simulation of water content infiltration: ERT data inverted with a $0.5 \mathrm{~m}$ electrode spacing (ABCD) and a large electrode spacing (EFGH). (a) and $€$ background electrical resistivity distribution; (b) and (f) relative change of electrical resistivity; (c) and (g) background water content distribution; (d) and (h) absolute water content change. The vertical dotted lines locate the 1D profile presented at Fig. 6 .

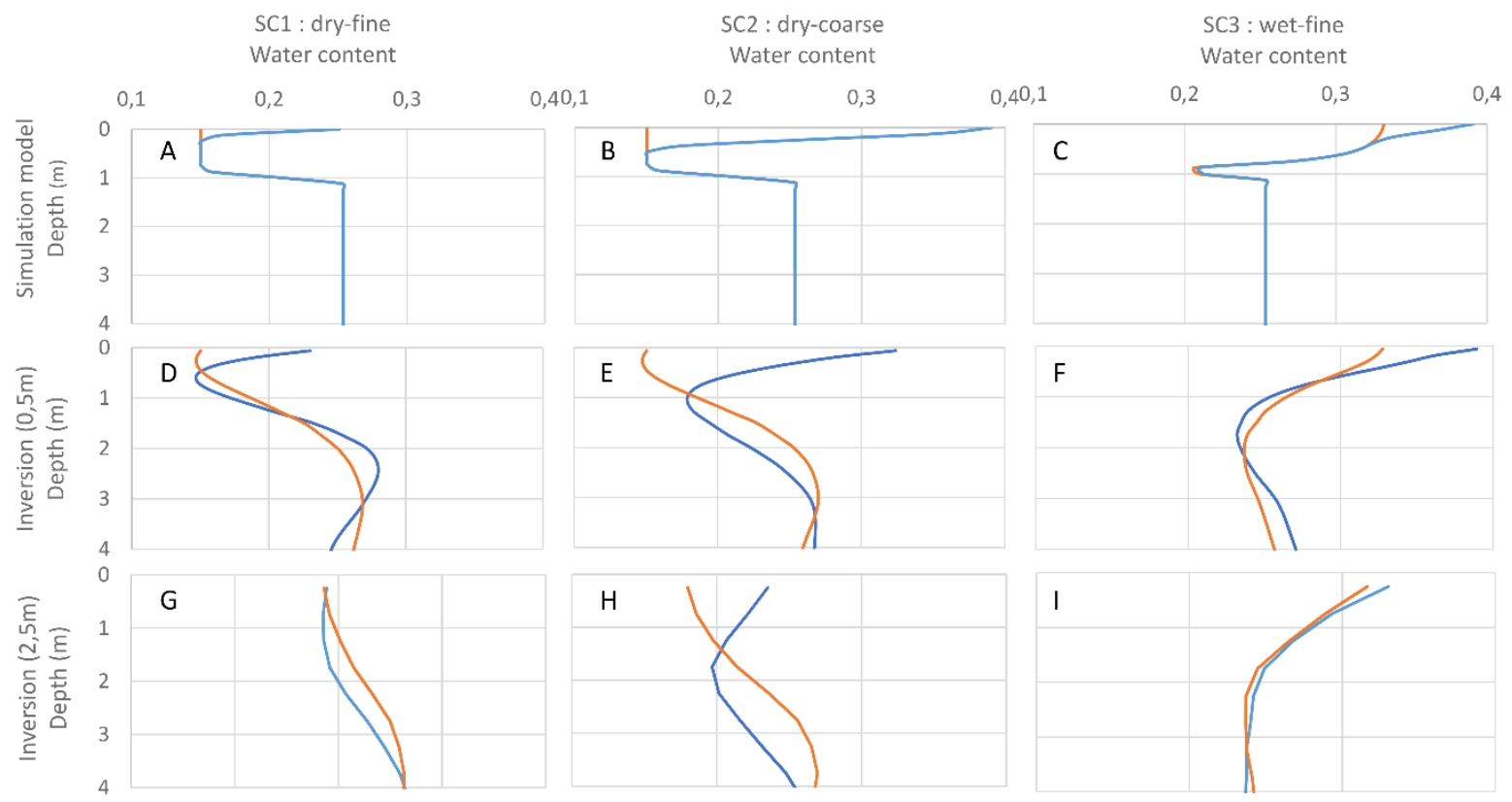

Figure 6: pre(red)- and post(blue)- infiltration water content values for: abc. the HYDRUS-2D model; def. high resolution ERT inversion; ghi. low resolution ERT inversion; (a,d,g). dry fine cover layer; (b,e,h). dry coarse cover layer; (c,f,i). wet thin cover layer (from Dumont et al., 2017). 
Hydrol. Earth Syst. Sci. Discuss., https://doi.org/10.5194/hess-2018-163

Manuscript under review for journal Hydrol. Earth Syst. Sci.

Discussion started: 31 May 2018

(c) Author(s) 2018. CC BY 4.0 License.

\section{(c) (i)}

Hydrology and Earth System Sciences

Discussions

\begin{tabular}{|c|c|c|c|c|c|c|c|c|c|c|c|c|c|}
\hline & \multicolumn{4}{|c|}{ SC1: fine and dry } & \multicolumn{4}{|c|}{ SC2: Coarse and dry } & \multicolumn{4}{|c|}{ SC3: fine and wet } \\
\hline & & $\begin{array}{c}\text { Front } \\
\text { (m) }\end{array}$ & $\theta$ & $\Delta \theta$ & $\frac{\Delta \theta}{\theta}$ & $\begin{array}{c}\text { Front } \\
\text { (m) }\end{array}$ & $\theta$ & $\Delta \theta$ & $\frac{\Delta \theta}{\theta}$ & $\begin{array}{c}\text { Front } \\
(\mathrm{m})\end{array}$ & $\theta$ & $\Delta \theta$ & $\frac{\Delta \theta}{\theta}$ \\
\hline \multicolumn{2}{|c|}{ 兽 } & 0.25 & 0.15 & 0.015 & 0.099 & 0.5 & 0.15 & 0.072 & 0.48 & 0.375 & 0.33 & 0.015 & 0.045 \\
\hline \multirow{2}{*}{ 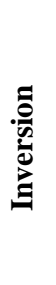 } & $\underset{\Xi}{\Xi}$ & 0.625 & 0.149 & 0.018 & 0.124 & 0.875 & 0.155 & 0.074 & 0.479 & 0.625 & 0.315 & 0.019 & 0.061 \\
\hline & 究 & 0.125 & 0.186 & 0.001 & 0.007 & 1.50 & 0.188 & 0.050 & 0.266 & 3 & 0.265 & 0.017 & 0.064 \\
\hline
\end{tabular}

Table 2: infiltration front features summary (front depth, volumetric water content $\theta$, absolute change of water content, relative change of water content) for the Hydrus-2D model, the high resolution ERT inversion and the low resolution ERT inversion.

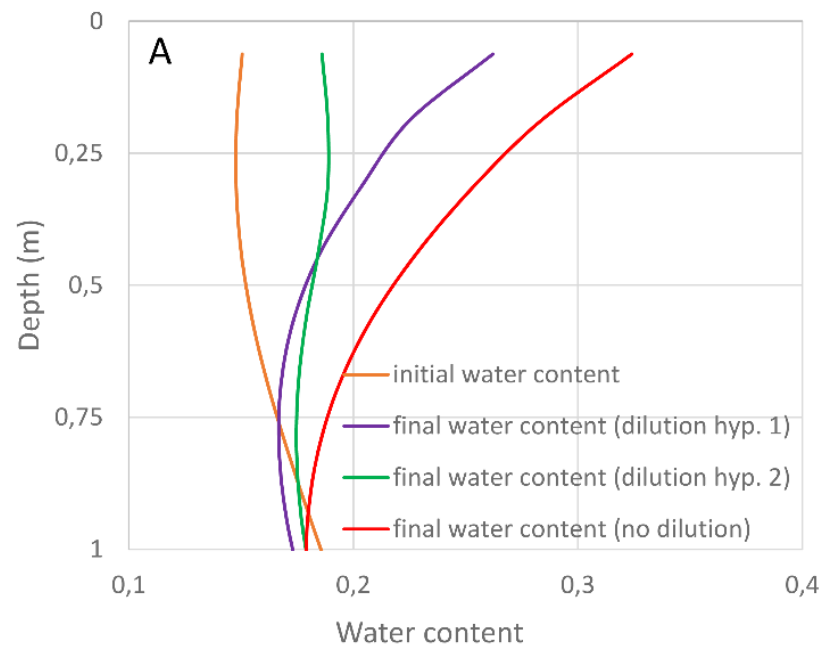

Water content

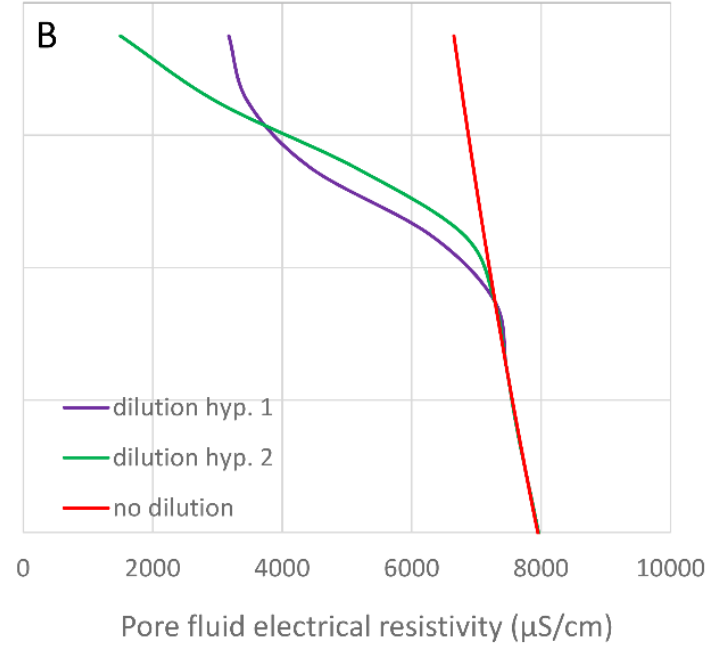


Hydrol. Earth Syst. Sci. Discuss., https://doi.org/10.5194/hess-2018-163

Manuscript under review for journal Hydrol. Earth Syst. Sci.

Discussion started: 31 May 2018

(c) Author(s) 2018. CC BY 4.0 License.

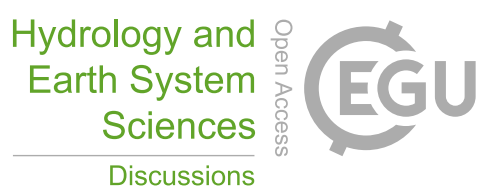

(c) (i)

Figure 7 : effect of the salinity dilution on the water content assessment from electrical resistivity data. (a) Computed initial and final water content when salinity dilution is neglected. (b) Pore fluid conductivity profiles with depth due to dilution effect for three dilution scenario (from Dumont et al., 2017). 